\title{
Kesan Gelombang Kejutan terhadap Sifat Mikromekanik Sambungan Pateri SAC 0307/ENiG menggunakan Pendekatan Pelekukan Nano
}

(Effect of Shock Wave on Micromechanical Properties of SAC 0307/ENiG Solder Joint using Nanoindentation Approach)

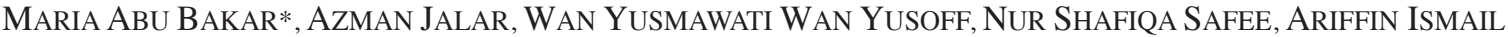 \\ NORLIZA ISMAIL, EMEE MARINA SALLEH \& NAJIB SAEDI IBRAHIM
}

\begin{abstract}
ABSTRAK
Kebolehharapan dan kebolehtahanan pempakejan elektronik bagi peralatan elektronik dalam bidang ketenteraan adalah menjangkaui kepenggunaan komersial. Kebolehharapan sambungan pateri merupakan perkara asas bagi penilaian prestasi pempakejan elektronik. Ujian kebolehharapan komersial atau konvensional seperti dalam standard JEDEC (Solid State Technology Association) tidak dapat memenuhi keperluan pempakejan elektronik untuk piawaian ketenteraan. Kajian ini melaporkan gerak balas sambungan logam pateri SAC 0307 pada papan litar bercetak (PCB) dengan kemasan permukaan electroless nickel immersion gold (ENiG) terhadap gelombang kejutan hasil daripada ujian letupan secara terbuka. Perubahan sifat mikromekanik dikaji menggunakan pendekatan pelekukan nano. Gelombang kejutan yang berbeza dikenakan pada sambungan pateri dengan menggunakan bahan Emulex dengan dos sebanyak $700 \mathrm{~g}$ dan 1500 g. Kekerasan sambungan pateri telah menyusut sebanyak 29\% daripada 141 MPa kepada 100 MPa selepas didedahkan pada gelombang kejutan dengan penggunaan dos Emulex sebanyak 1500 g. Modulus terkurang sambungan pateri juga telah menyusut sebanyak $13 \%$ daripada 141 GPa kepada 123 GPa dengan penggunaan dos bahan Emulex sebanyak $1500 \mathrm{~g}$. Ujian gelombang kejutan telah menyebabkan berlakunya perubahan pada sifat mikromekanik sambungan pateri iaitu berlakunya kelakuan perlembutan yang melibatkan penyusutan nilai kekerasan dan modulus terkurang. Tiada retak diperhatikan pada antara sambungan pateri-substrat yang menunjukkan bahawa sambungan pateri adalah tidak gagal dan tetap utuh selepas didedahkan pada gelombang kejutan yang tinggi, walaupun berlaku penyusutan sifat mikromekanik yang ketara.
\end{abstract}

Kata kunci: Bahan pateri Sn-Ag-Cu; gelombang kejutan; pelekukan nano; sambungan pateri; sifat mikromekanik

\section{ABSTRACT}

Reliability and durability of electronic packaging for electronic equipment in military application is beyond commercial applicability. The reliability of a solder joint is a key point in assessing the performance of electronic packaging. Commercial or conventional reliability testing such as JEDEC (Solid State Technology Association) standard is unable to fulfill the electronic packaging requirement for military standards. This study reported the response of SAC 0307 solder joint on printed circuit board ( $P C B)$ with ENiG surface finish (electroless nickel immersion gold) towards shock waves resulting from an open-field blast test. Micromechanical properties changes were investigated using nanoindentation approach. The solder joints were exposed to shock wave test using different doses of Emulex, $700 \mathrm{~g}$ and $1500 \mathrm{~g}$, respectively. The solder joint's hardness has decreased 29\% from $141 \mathrm{MPa}$ to $100 \mathrm{MPa}$ after subjected to shock wave using $1500 \mathrm{~g}$ Emulex. The shock wave has led to the changes in micromechanical properties of the solder joints in terms of softening behaviour i.e. the decreasing of hardness and reduced modulus values. However, no cracks were observed between solder-substrate indicate that the solder joint is not fail and remains strong after subjected to high shock wave, despite the significant reduction in micromechanical properties.

Keywords: Micromechanical properties; nanoindentation; shock wave; solder joint; solder materials $\mathrm{Sn}$-Ag-Cu

\section{PENGENALAN}

Gelombang kejutan adalah suatu keadaan tenaga dibebaskan oleh ledakan bahan letupan pada masa yang singkat, menghasilkan gelombang bertekanan tinggi daripada sumber tenaga di dalam atmosfera (Scott et al. 2017). Ujian gelombang kejutan merupakan salah satu daripada ujian kebolehharapan dalam persekitaran lampau yang sangat penting terutamanya bagi aplikasi ketenteraan. Gelombang kejutan hasil daripada ledakan bahan letupan semasa peperangan bukan sahaja mengancam musuh, malah akan memusnahkan peralatan elektronik ketenteraan secara langsung. Banyak penyelidikan telah dijalankan untuk mengkaji kesan gelombang kejutan ke atas perubahan sifat mekanik serta struktur bahan antaranya seperti konkrit, komposit, kaca dan besi keluli (Abbas et al. 2019; Coles et al. 2017; Hao et al. 2016; Seica et al. 2019). Walau bagaimanapun, kajian kesan gelombang kejutan terhadap struktur sambungan peranti elektronik masih 
kurang dilaporkan. Sambungan pateri telah digunakan secara meluas untuk memberi sambungan mekanik dan elektrik bagi membolehkan suatu peranti dapat berfungsi dengan baik termasuklah peralatan elektronik yang digunakan dalam ketenteraan. Kegagalan struktur mekanik sambungan pateri akan mengakibatkan suatu peranti tidak dapat berfungsi dengan baik. Kebolehharapan sambungan pateri adalah sangat penting bagi jangka hayat pakej elektronik kerana sambungan pateri dalam pakej elektronik terdedah kepada kegagalan di bawah keadaan persekitaran seperti suhu, kelembapan, habuk, kejutan dan getaran (Myung et al. 2016). Sebagai contoh, bagi aplikasi aeroangkasa, adalah sangat penting untuk mengekalkan kebolehharapan peranti elektronik sekurang-sekurangnya selama 20 tahun (Marques et al. 2014). Terdapat pelbagai jenis ujian berdasarkan piawai yang dijalankan bagi menentukan kebolehharapan sambungan pateri. Antaranya seperti ujian kejutan terma (Kang et al. 2016), ujian periuk tekanan (РСT) (Zhang \& Paik 2016), ujian getaran (Che \& Pang 2015), ujian kitaran terma (TC) (Kwon et al. 2016) dan ujian penyimpanan suhu tinggi (HTS) (Jalar et al. 2018; Mustafa et al. 2016). Kajian kesan gelombang kejutan terhadap sambungan pateri adalah sangat penting untuk mengetahui kebolehharapan dan kebolehtahanan peralatan elektronik yang digunakan oleh tentera ketika peperangan. Peralatan elektronik ketenteraan yang biasa digunakan ketika peperangan untuk tujuan komunikasi antaranya seperti radio, telefon dan alat navigasi. Ketika peperangan, peralatan elekronik ini sangat terdedah kepada persekitaran lampau seperti tekanan yang tinggi oleh ledakan bom. Kajian terkini hanya memberi fokus terhadap ketahanan pakej luaran peranti elektronik berbanding dengan kebolehharapan keadaan sambungan pateri peranti tersebut. Kajian terhadap sifat mekanik sambungan pateri di bawah keadaan kejutan gelombang adalah sangat penting bagi menjangkakan hayat peranti elektronik bagi aplikasi ketenteraan.

Kelakuan mekanik sambungan pateri merupakan perkara yang penting dalam isu kebolehharapan sesuatu pakej atau produk elektronik. Kajian terdahulu telah menggunakan kaedah konvensional dalam mendapatkan sifat mekanik aloi pateri iaitu ujian mikrokekerasan, ujian ricih, ujian hentaman, ujian Vickers, ujian lenturan dan ujian tegangan (Ali et al. 2016; Eid et al. 2016; Santos et al. 2015; Sujan et al. 2016; Wang et al. 2016). Kajian Giuranno et al. (2016) telah melaporkan berkaitan sifat mekanik aloi pateri SAC menggunakan kaedah Vickers dengan membuat pelekukan pada kawasan pateri dan kawasan substrat. Walau bagaimanapun, kaedah tersebut adalah kaedah yang konvensional serta hanya dapat memberikan sifat mekanik secara pukal. Oleh itu, teknik pendekatan pelekukan nano iaitu teknik yang diadaptasikan bagi mendapatkan sifat mekanik secara setempat (Abdullah et al. 2018). Ujian pelekukan ini juga boleh digunakan untuk menghitung modulus elastik, eksponen pengerasan terikan, keliatan patah (bagi bahan rapuh), sifat likat-kenyal, retak, rayapan, perubahan fasa dan tenaga penyerapan. Ujian pelekukan nano dipertimbangkan sebagai ujian tanpa musnah dan kelebihannya adalah dapat mencirikan sifat mikromekanik bagi sampel yang sangat kecil. Teknik pelekukan nano ini telah digunakan secara meluas untuk mencirikan sifat mekanik struktur dalam skala yang kecil tanpa pemusnahan sampel, memberikan kawalan beban yang jitu, kedalaman dan kedudukan pelekukan. Maklumat sifat mekanik dan deformasi bahan dapat diperoleh berdasarkan lengkung beban-kedalaman. Contohnya, nilai kekerasan dan modulus Young dapat diperoleh daripada beban maksimum dan permulaan cerun pembebanan seperti yang dicadangkan oleh Oliver dan Pharr (2004). Ujian pelekukan nano juga telah digunakan untuk menentukan modulus Young dan kekerasan filem nipis, perubahan mikrostruktur dan bahan pukal (Cheng et al. 2017). Kajian oleh Chen et al. (2015) telah menggunakan ujian pelekukan nano untuk mengkaji sifat mekanik struktur sambungan pateri, pateri pukal dan keadaan selepas pematerian.

Kajian penyelidik terdahulu ke atas aloi logam akibat daripada pendedahan gelombang kejutan mendapati ia menyusutkan sifat aloi dan mengakibatkan mekanisme ubah bentuk. Kajian oleh Ignatova et al. (2010) mendapati, sifat mikrostruktur dalaman dan sifat mekanik logam kuprum berbutiran halus bergantung kepada keamatan gelombang kejutan yang dikenakan. Gelombang kejutan dengan keamatan kurang daripada 25-50 GPa tidak memberi kesan ke atas sifat mikrostruktur dan mekaniknya manakala dengan keamatan melebihi $55 \mathrm{GPa}$, ia mengurangkan ketumpatan kehelan dan meningkatkan saiz butiran sekaligus menyusutkan sifat mekanik logam kuprum yang dikaji. Walau bagaimanapun, kajian oleh Kulkuv et al. (2013) mendapati aloi aluminium yang didedahkan pada gelombang kejutan dapat meningkatkan sifat kekerasan serta kekuatan alah aloi tersebut.

Dalam kajian ini, ujian gelombang kejutan digunakan untuk memahami sifat mekanik sambungan pateri akibat pendedahan kepada persekitaran yang lampau. Sambungan pateri bebas plumbum, SAC 0307 pada papan litar bercetak (PCB) dengan kemasan permukaan ENiG didedahkan pada gelombang kejutan yang berbeza. Perubahan mikrostruktur sambungan pateri serta sifat mikromekanik daripada segi kekerasan dan modulus terkurang dianalisis.

\section{BAHAN DAN KAEDAH}

Pes aloi pateri bebas plumbum terdiri daripada $99 \% \mathrm{Sn}$, $0.3 \% \mathrm{Ag}$ dan $0.7 \% \% \mathrm{Cu}$ (SAC 0307) dicetak menggunakan stensil pada papan litar bercetak (PCB) dengan kemasan permukaan ENiG. Papan PCB/ENiG yang telah dicetak akan dipaterikan menerusi proses aliran semula pada suhu $260^{\circ} \mathrm{C}$ (Ismail et al. 2018). Sambungan pateri SAC 0307 pada PCB/ ENiG ini seterusnya didedahkan pada ujian gelombang kejutan. Rajah 1 menunjukkan illustrasi kedudukan sampel semasa ujian gelombang kejutan. Sampel sambungan pateri SAC $0307 /$ ENiG bersaiz $5 \mathrm{~mm} \times 3 \mathrm{~mm} \times 1 \mathrm{~mm}$ dibalut dalam kain satin dan digantung pada papan kayu dengan ketinggian $1 \mathrm{~m}$ daripada paras tanah dan $2 \mathrm{~m}$ daripada bahan letupan. Untuk menghasilkan gelombang kejutan, bahan Emulex sebanyak $700 \mathrm{~g}$ dan $1500 \mathrm{~g}$ digunakan dan 
akan diletupkan secara ledakan terbuka. Bahan Emulex ini ditimbang terdahulu dan kemudian dibungkus di dalam plastik dan digantung dengan ketinggian 1 meter dari paras tanah. Jarak bahan letupan dengan sampel adalah 2 meter. Alat pengukur tekanan diletakkan di sebelah sampel dan bacaan tekanan gelombang kejutan diukur sepanjang ujian berlaku. Perisian BLASTDAQ digunakan untuk mengukur tekanan gelombang kejutan.

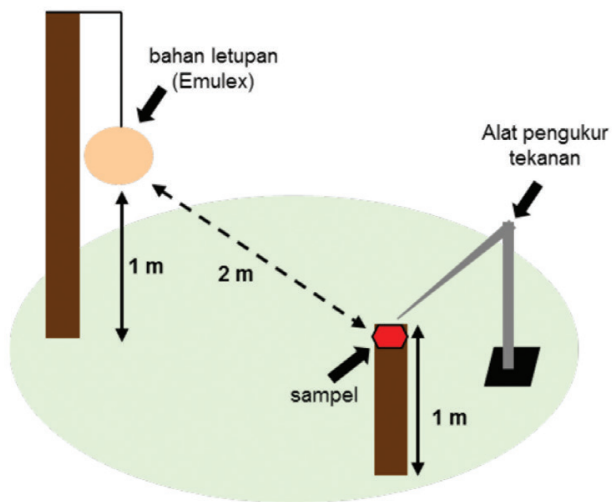

RAJAH 1. Ilustrasi kedudukan sampel semasa ujian gelombang kejutan

Setelah selesai ujian gelombang kejutan, pemeriksaan fizikal ke atas sampel akan dilakukan. Untuk mencirikan sifat fizik dan sifat mikromekanik sambungan pateri, teknik metalografi digunakan untuk menyediakan keratan rentas sambungan pateri. Sampel dipotong menggunakan mesin pemotong dengan mata pemotong berlian. Kemudian, klip sampel digunakan untuk memegang sampel di dalam acuan cagak. Campuran serbuk resin pengeras (VersoCit-2 Powder, Struers) dan cecair resin epoksi (VersoCit-2 liquid, Struers) digunakan untuk mencagak sampel. Sampel akan siap dicagak pada suhu bilik selama $4 \mathrm{j}$. Selesai dicagak, sampel telah sedia untuk proses lelasan. Proses lelasan dijalankan dengan menggunakan kertas las SiC (Buehler) dari 400 grit, 600 grit, 800 grit, 1200 grit hingga 2000 grit. Proses akhir ialah proses penggilapan menggunakan semburan berlian bersaiz $1 \mu \mathrm{m}$ (Struers). Kemudian pencerapan mikrostuktur sambungan pateri akan dicerap dengan menggunakan mikroskop fokus tidak terhingga (IFM) dengan pembesaran $100 \times$.

Pencirian sifat mikromekanik dilakukan dengan menggunakan alat pelekukan nano (Micro Materials, NanoTest ${ }^{T M}$ ). Mesin pelekukan nano ini merupakan alat yang boleh memberikan maklumat sifat mikromekanik seperti nilai kekerasan, modulus terkurang, kerja plastik dan kerja elastik. Jenis uji kaji dalam ujian pelekukan nano ialah histeresis beban melawan kedalaman. Beban maksimum yang dikenakan ke atas permukaan keratan sampel ialah sebanyak $10 \mathrm{mN}$ (Bakar et al. 2016). Kadar $0.5 \mathrm{mN} / \mathrm{s}$ digunakan bagi proses pembebanan dan pelepasan beban dan masa inap adalah selama $30 \mathrm{~s}$.

\section{KEPUTUSAN DAN PERBINCANGAN}

Kajian ini memfokuskan sifat mikromekanik sambungan aloi pateri selepas ujian gelombang kejutan. Kelakuan mekanik sambungan pateri merupakan perkara yang sangat penting dalam menilai kebolehharapan sesuatu pempakejan atau produk elektronik. Rajah 2 menunjukkan graf bacaan tekanan semasa uji kaji gelombang kejutan dengan penggunaan bahan Emulex yang berbeza. Pencerapan nilai tekanan semasa ujian gelombang kejutan dilakukan selama 0.075 s. Penggunaan bahan Emulex dengan dos $1500 \mathrm{~g}$ telah menghasilkan tekanan gelombang maksimum pada masa $0.05 \mathrm{~s}$ adalah $82 \mathrm{MPa}$; lima kali ganda berbanding dengan dos Emulex sebanyak 700 g, sekitar 14 MPa seperti yang diringkaskan dalam Rajah 3.


RAJAH 2. Graf bacaan tekanan semasa ujian gelombang kejutan dengan dos Emulex, (a) $700 \mathrm{~g}$ dan (b) $1500 \mathrm{~g}$

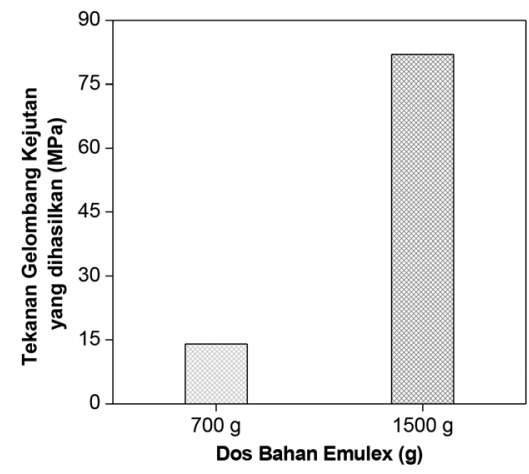

RAJAH 3. Nilai tekanan gelombang kejutan yang terhasil dengan dos bahan Emulex berbeza 
Rajah 4 menunjukkan profil tipikal beban melawan kedalaman bagi sambungan pateri selepas ujian gelombang kejutan dengan dos berbeza. Plot profil beban melawan bagi sampel sebelum ujian gelombang kejutan menunjukkan profil tipikal tetapi menunjukkan perbezaan daripada segi kedalaman yang lebih tinggi bagi sampel selepas ujian gelombang kejutan. Keputusan ini adalah seiring dengan keputusan kedalaman maksimum dan plastik seperti di dalam Rajah 5. Kedalaman maksimum dan plastik meningkat dengan peningkatan dos bahan Emulex. Nilai kedalaman yang semakin tinggi menunjukkan bahan pateri mengalami kelakuan perlembutan akibat daripada ujian gelombang kejutan.

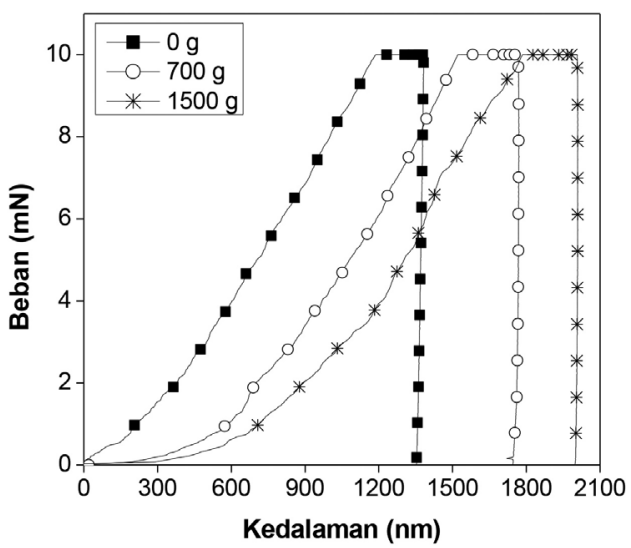

RAJAH 4. Profil beban melawan kedalaman bagi sambungan pateri SAC 0307/ENiG selepas ujian gelombang kejutan yang berbeza

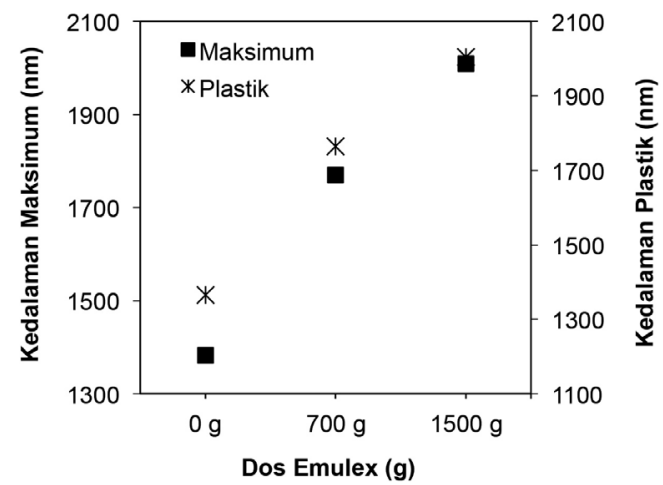

RAJAH 5. Kedalaman maksimum dan plastik bagi sambungan pateri SAC 0307/ENiG selepas ujian gelombang kejutan yang berbeza

Rajah 6 menunjukkan nilai kekerasan sambungan pateri SAC 0307/ENiG selepas ujian gelombang kejutan yang berbeza. Nilai kekerasan telah menurun daripada $141 \mathrm{MPa}$ kepada $128 \mathrm{MPa}$ dengan dos Emulex $700 \mathrm{~g}$, dan menyusut kepada $100 \mathrm{MPa}$ dengan dos Emulex 1500 g. Keputusan menunjukkan bahawa kekerasan telah menyusut sebanyak $29 \%$ selepas didedahkan dengan ujian gelombang kejutan. Modulus terkurang juga menunjukkan penyusutan sebanyak 13\% daripada 141 GPa kepada 135 GPa dengan dos Emulex $700 \mathrm{~g}$ dan $123 \mathrm{GPa}$ dengan dos Emulex 1500 g (Rajah 7). Keputusan kekerasan yang mengurang ini adalah seiring dengan keputusan kedalaman pelekukan, juga menunjukkan bahan pateri semakin lembut. Kelakuan perlembutan dalam bahan logam juga biasanya berlaku disebabkan oleh perubahan mikrostruktur akibat tindakan termodinamik seperti suhu dan masa. Bakar et al. (2016) telah melaporkan tentang sambungan pateri SAC 305 juga mengalami kelakuan perlembutan dengan penurunan kekerasan daripada $250 \mathrm{MPa}$ kepada $150 \mathrm{MPa}$ selepas ujian penyimpanan suhu tinggi selama 1000 jam. Kelakuan perlembutan dalam kajian ini adalah disebabkan oleh sambungan pateri bersifat mulur akibat gelombang kejutan. Kejutan gelombang bukan sahaja menghasilkan tekanan yang tinggi malah pendedahan suhu yang tinggi turut berlaku (Rajendran \& Lee 2009).



RAJAH 6. Nilai kekerasan sambungan pateri SAC 0307/ENiG selepas ujian gelombang kejutan yang berbeza

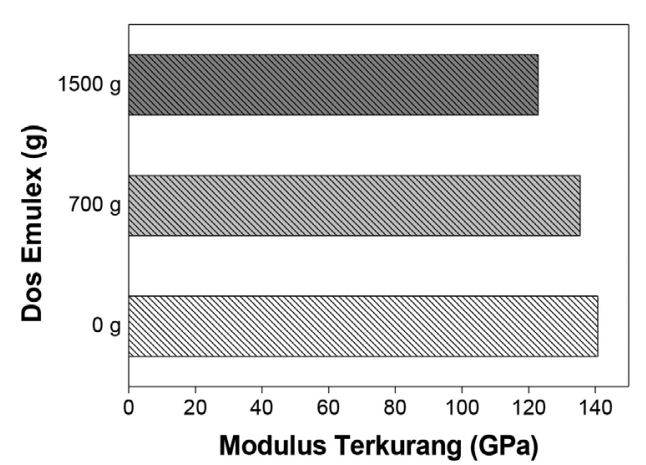

RAJAH 7. Nilai modulus terkurang sambungan pateri SAC 0307/ENiG selepas ujian gelombang kejutan yang berbeza

Keretakan sambungan pateri merupakan mekanisme kegagalan dan menjadi penanda aras kepada penyelidik dalam mengkaji kebolehharapan sambungan pateri dalam pempakejan mikroelektronik (Liu et al. 2017). Dalam kajian ini, sambungan pateri kelihatan masih utuh dan tidak gagal sebagai mana tiada retak diperhatikan pada antara sambungan pateri-substrat (Rajah 8). Jika dilihat kesan gelombang kejutan ke atas bahan konkrit seperti dalam laporan Zeng et al. (2018), tekanan yang 
didedahkan sekitar 0.8-3.6 MPa telah mengakibatkan keretakan pada struktur bahan konkrit tersebut. Keputusan kajian ini adalah berlawanan dengan hasil kajian yang melibatkan kesan ujian kebolehharapan yang lain seperti ujian penuaan sesuhu, kitaran terma, ujian gegaran yang menunjukkan pembentukan lompang dan retak (An et al. 2018; Lee et al. 2010). Kajian oleh Gu et al. (2018) telah menunjukkan retak terhasil akibat daripada ujian kitaran terma dan ujian jatuh. Pertumbuhan lapisan sebatian antara logam (IMC) juga sering diperhatikan oleh para pengkaji kerana ia sering dihubungkaitkan dengan kebolehharapan suatu sambungan. Kajian ini menunjukkan nilai ketebalan lapisan IMC menunjukkan perubahan yang minimum iaitu daripada $1.96 \mu \mathrm{m}$ bagi sampel tanpa pendedahan kejutan gelombang, meningkat sedikit kepada $2.74 \mu \mathrm{m}$ bagi dos $700 \mathrm{~g}$ Emulex dan $3.62 \mu \mathrm{m}$ bagi $1500 \mathrm{~g}$ Emulex. Kajian ini menunjukkan bahawa perubahan ketebalan lapisan IMC akibat kejutan gelombang adalah sangat kecil jika dibandingkan dengan perubahan lapisan IMC akibat ujian kebolehharapan yang lain, contohnya ujian penuaan sesuhu yang menghasilkan lapisan IMC mencecah kepada $10 \mu \mathrm{m}$ ke atas ( $\mathrm{Hu}$ et al. 2014). Pembentukan lompang yang banyak akan menyebabkan retak terhasil pada kawasan lapisan IMC dan ia terhasil akibat daripada pekali pengembangan terma (CTE) yang berbeza.
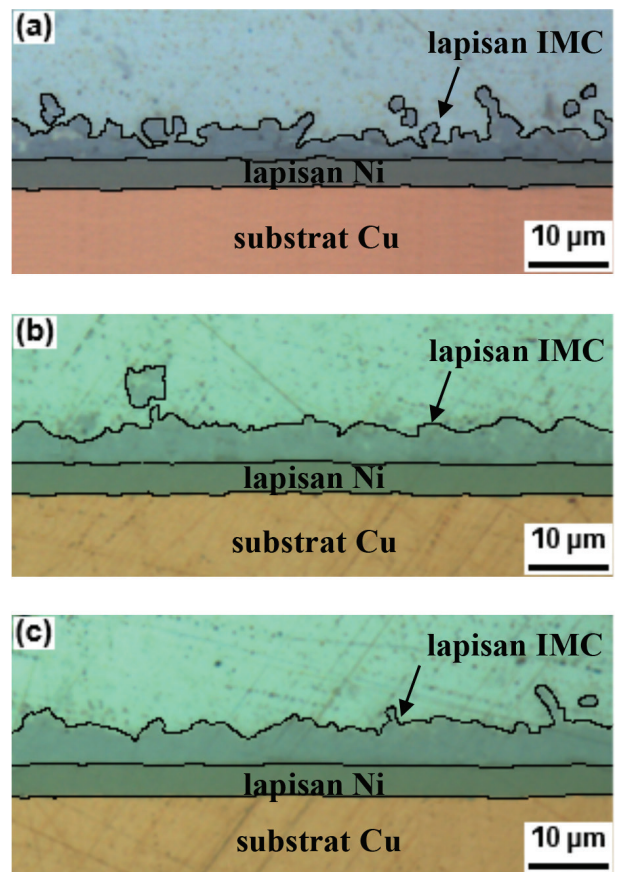

RAJAH 8. Mikrograf sambungan pateri SAC 0307/ENiG selepas ujian kejutan gelombang dengan dos Emulex, (a) $700 \mathrm{~g}$ dan (b) $1500 \mathrm{~g}$

Walaupun daya atau tekanan yang dikenakan ke atas sambungan pateri semasa ujian gelombang kejutan adalah sangat tinggi, namun kesan ujian gelombang kejutan adalah tidak menunjukkan kesan seperti impak daya fizikal luaran yang lain contohnya seperti ketukan dan hentaman yang menjurus kepada kegagalan fizikal suatu sambungan. Walau bagaimanapun, ujian gelombang kejutan telah menyebabkan berlakunya penyusutan sifat mikromekanik sebagai mana yang telah ditunjukkan pada perubahan nilai kekerasan dan modulus.

\section{KESIMPULAN}

Teknik pelekukan nano ini telah dapat mencirikan sifat mikromekanik secara setempat dan memberikan maklumat terperinci berkaitan kelakuan sambungan pateri selepas didedahkan kepada ujian gelombang kejutan. Ujian gelombang kejutan dengan penggunaan dos bahan Emulex yang tinggi, $1500 \mathrm{~g}$ telah menyebabkan kestabilan sambungan pateri telah menyusut iaitu berlakunya kelakuan perlembutan, canggaan plastik yang tinggi serta penurunan nilai modulus terkurang. Namun begitu, sambungan pateri adalah masih utuh dan tidak gagal selepas ujian gelombang kejutan sebagai mana tiada retak diperhatikan pada antara sambungan pateri-substrat.

\section{PENGHARGAAN}

Penulis merakamkan penghargaan kepada Universiti Kebangsaan Malaysia menerusi geran penyelidikan MI2018-019, Universiti Pertahanan Nasional Malaysia, Kementerian Pendidikan Tinggi menerusi geran penyelidikan FRGS/1/2015/SG06/UPNM/03/1 dan pihak RedRing Solder (M) Sdn. Bhd. atas kolaborasi projek ini serta sumbangan bahan penyelidikan.

\section{RUJUKAN}

Abbas, A., Adil, M., Ahmad, N. \& Ahmad, I. 2019. Behavior of reinforced concrete sandwiched panels (RCPs) under blast load. Engineering Structures 181: 476-490.

Abdullah, I., Zulkifli, M.N.A., Jalar, A. \& Ismail. R. 2018 Deformation behavior relationship between tensile and nanoindentation tests of SAC305 lead-free solder wire. Soldering \& Surface Mount Technology 30(3): 194-202.

Ali, B., Sabri, M.F.M., Jauhari, I. \& Sukiman, N.L. 2016. Impact toughness, hardness and shear strength of $\mathrm{Fe}$ and $\mathrm{Bi}$ added Sn-1 Ag-0.5Cu lead-free solders. Microelectronics Reliability 63: 224-230.

An, T., Fang, C., Qin, F., Li, H., Tang, T. \& Chen, P. 2018. Failure study of $\mathrm{Sn} 37 \mathrm{~Pb}$ PBGA solder joints using temperature cycling, random vibration and combined temperature cycling and random vibration tests. Microelectronics Reliability 91: 213-226.

Bakar, M.A., Jalar, A., Daud, A.R., Ismail, R., Lah, N.C.A. \& Ibrahim, N.S. 2016. Nanoindentation approach on investigating micromechanical properties of joining from green solder materials. Sains Malaysiana 45(8): 1275-1279.

Coles, L.A., Tilton, C., Roy, A., Shula, A. \& Silberschmidt, V.V. 2017. Dynamic damage in woven carbon/epoxy composites due to air blast. Procedia Structural Integrity 6: 5-10.

Che, F.X. \& Pang, J.H.L. 2015. Study on reliability of PQFP assembly with lead free solder joints under random vibration test. Microelectronics Reliability 55: 2769-2776. 
Chen,D.Q.,Zhou, G.Y.,Liu,Z.P.\& Tu,S.T.2015.Nanoindentation experimental study on mechanical properties of as-cast BNi-2 solder alloy. Procedia Engineering 130: 652-661.

Cheng, G., Sun, X., Wang, Y., Tay, S.L. \& Gao, W. 2017. Nanoindentation study of electrodeposited Ag thin coating: An inverse calculation of anisotropic elastic-plastic properties. Surface \& Coatings Technology 310: 43-50.

Eid, A., Foud, A.N. \& Durai, E.M. 2016. Effect of adding $0.5 \mathrm{wt} \% \mathrm{ZnO}$ nanoparticles, temperature and strain rate on tensile properties of Sn-5.0 wt\% Sb-0.5 wt\% Cu (SSC505) lead free solder alloy. Materials Science and Engineering A 657: 104-114.

Giuranno, D., Delsante, S., Borzone, G. \& Novakovic, R. 2016. Effects of $\mathrm{Sb}$ addition on the properties of $\mathrm{Sn}-\mathrm{Ag}-\mathrm{Cu} / \mathrm{Cu}$, $\mathrm{Ni}$ ) solder systems. Journal of Alloys and Compounds 689: 913-930.

Gu, J., Lin, J., Lei, Y. \& Fu, H. 2018. Experimental analysis of $\mathrm{Sn}_{3.0} \mathrm{Ag}_{-}{ }_{0.5} \mathrm{Cu}$ solder joint board-level drop/vibration impact failure models after thermal/isothermal aging. Microelectronics Reliability 80: 29-36.

Hao, H., Hao, Y., Li, J. \& Chen, W. 2016. Review of the current practices in blast-resistant analysis and design of concrete structures. Advances in Structural Engineering 19(8): 1-31.

Hu, X., Li, Y., Liu, Y., Liu, Y. \& Min, Z. 2014. Microstructure and shear strength of $\mathrm{Sn} 37 \mathrm{~Pb} / \mathrm{Cu}$ solder joints subjected to isothermal aging. Microelectronics Reliability 54(8): 15751582 .

Ignatova, O.N., Kaganova, I.I., Malyshev, A.N., Podurets, A.M., Raevskii, V.A., Skokov, V.I., Tkachenko, M.I., Salishchev, G.A.\& Kon'kova, T.N. 2010. Effect of shock wave loading on the internal microstructure and mechanical properties of fine-grained copper. Combustion, Explosion and Shock Waves 46(6): 719-723.

Ismail, N., Jalar, A., Bakar, M.A. \& Ismail, R. 2018. Effect of carbon nanotube addition on the growth of intermetallic layer of $\mathrm{Sn}-\mathrm{Ag}-\mathrm{Cu}$ solder system under thermal aging. Sains Malaysiana 47(7): 1585-1590.

Jalar, A., Bakar, M.A., Ismail, R., Ibrahim, N.S. \& Ambak, M.A. 2018. Effect of coloured pigment on intermetallic compound growth of $\mathrm{Sn}-{ }_{3.0} \mathrm{Ag}_{-0.5} \mathrm{Cu}$ solder joint. Sains Malaysiana 47(5): 1005-1010.

Kang, M.S., Jeon, Y.J., Kim, D.S. \& Shin, Y.E. 2016. Degradation characteristics and $\mathrm{Ni}_{3} \mathrm{Sn}_{4}$ IMC growth by a thermal shock test in SAC305 solder joints of MLCCs applied in automotive electronics. International Journal of Precision Engineering and Manufacturing 17(4): 445-452.

Kulkov, S.N., Vorozhtsov, S.A., Komarov, V.F. \& Promakhov, V.V. 2013. Structure, phase composition and mechanical properties of aluminium alloys produced by shock-wave compaction. Russian Physics Journal 56(1): 85-89.

Kwon, Y.H., Bang, H.S. \& Bang, H.S. 2016. Viscoplasticity behaviour of a solder joint on a drilled $\mathrm{Cu}$ pillar bump under thermal cycling using FEA. Journal of Electronic Materials 46(2): 833-840.

Lee, T.K., Ma, H., Liu, K.C. \& Xue, J. 2010. Impact of isothermal aging on long-term reliability of fine-pitch ball grid array packages with $\mathrm{Sn}-\mathrm{Ag}-\mathrm{Cu}$ solder interconnects: Surface finish effects. Journal of Electronic Materials 39(12): 2564-2573.

Liu, E., Zhaner, T., Besold, S., Wunderle, B. \& Elger, G. 2017. Location resolved transient thermal analysis to investigate crack growth in solder joints. Microelectronics Reliability 79: 533-546.
Marques, V.M.F., Jonston, C. \& Grant, P.S. 2014. Microstructural evolution at $\mathrm{Cu} / \mathrm{Sn}-\mathrm{Ag}-\mathrm{Cu} / \mathrm{Cu}$ and $\mathrm{Cu} / \mathrm{Sn}-\mathrm{Ag}-\mathrm{Cu} / \mathrm{Ni}-\mathrm{Au}$ ball grid array interfaces during thermal ageing. Journal of Alloys and Compounds 613: 387-394.

Mustafa, M., Suhling, J.C. \& Lall, P. 2016. Experimental determination of fatigue behavior of lead free solder joints in microelectronic packaging subjected to isothermal aging. Microelectronics Reliability 56: 136-147.

Myung, W.R., Kim, Y., Kim, K.Y. \& Jung, S.B. 2016. Drop reliability of epoxy-contained Sn-58 wt.\% Bi solder joint with ENIG and ENEPIG surface finish under temperature and humidity test. Journal of Electronic Materials 45(7): 3651-3658.

Oliver, W.C. \& Pharr, G.M. 2004. Measurement of hardness and elastic modulus by instrumented indentation: Advances in understanding and refinements to methodology. Journal of Materials Research 19(1): 3-20.

Rajendran, R. \& Lee, J.M. 2009. Blast loaded plates. Marine Structure 22: 99-127.

Seica, M.V., Packer, J.A. \& Yankelevsky, D.Z. 2019. Blast and impact loading effects on glass and steel elements and materials. Thin-Walled Structures 134: 384-394.

Sujan, G.K., Haseebm, A.S.M.A., Nishikawa, H. \& Amalina, M.A. 2016. Interfacial reaction, ball shear strength and fracture surface analysis of lead-free solder joints prepared using cobalt nanoparticle doped flux. Journal of Alloys and Compounds 695: 981-990.

Santos, W.L.R., Brito, C., Bertelli, F., Spimelli, J.E. \& Garcia, A. 2015. Microstructural development of hypoeutectic Zn-(1040) wt $\%$ Sn solder alloys and impacts of interphase spacing and macrosegregation pattern on hardness. Journal of Alloys and Compounds 647: 989-996.

Wang, F., Huang, Y. \& Du, C. 2016. Mechanical properties of $\mathrm{SnBi}-\mathrm{SnAgCu}$ composition mixed solder joints using bending test. Materials Science \& Engineering A 668: 224-233.

Zhang, S. \& Paik, K.W. 2016. A study on the failure mechanism and enhanced reliability of Sn58Bi solder anisotropic conductive film joints in a pressure cooker test due to polymer viscoelastic properties and hydroswelling. IEEE Transactions on Components, Packaging and Manufacturing Technology 6(2): 216-223.

Maria Abu Bakar*, Azman Jalar, Norliza Ismail \& Emee Marina Salleh

Institut Kejuruteraan Mikro dan Nanoelektronik (IMEN)

Universiti Kebangsaan Malaysia

43600 UKM Bangi, Selangor Darul Ehsan

Malaysia

Azman Jalar

Pusat Pengajian Fizik Gunaan

Fakulti Sains dan Teknologi

Universiti Kebangsaan Malaysia

43600 UKM Bangi, Selangor Darul Ehsan

Malaysia

Wan Yusmawati Wan Yusoff, Nur Shafiqa Safee \& Ariffin Ismail Pusat Asasi Pertahanan

Universiti Pertahanan Malaysia

3, Kem Sungai Besi

57000 Kuala Lumpur, Wilayah Persekutuan

Malaysia 
Najib Saedi Ibrahim

Redring Solder (M) Sdn. Bhd.

Lot 17486, Jalan Dua, Taman Selayang Baru

68100 Batu Caves, Selangor Darul Ehsan

Malaysia
*Pengarang untuk surat-menyurat; email: maria@ukm.edu.my

Diserahkan: 2 Januari 2019

Diterima: 28 Februari 2019 